\title{
SENYAWA FENOLIK DALAM FRAKSI AKTIF KULIT BUAH Eleiodoxa conferta YANG BERPOTENSI ANTIBAKTERI TERHADAP BAKTERI Streptococcus mutans
}

\author{
Selvia Pratiwi Tri Sasmito'), Wulandari' ${ }^{1)}$, Endang Dwi Wulansari ${ }^{1 *}$ \\ 1) STIFAR "Yayasan Pharmasi Semarang" \\ Jl. Letjend. Sarwo Edi Wibowo Km.1 Plamongansari-Pucanggading, Semarang, Jawa Tengah \\ Korespondensi: dewi_stifar@yahoo.com
}

\begin{abstract}
Eleiodoxa conferta (Griff.) Buret fruit peel which is a material that is not widely used, has been studied for antibacterial activity against Streptococcus mutans. Extraction was carried out using solvents with stratified polarity, n-hexane, dichloromethane and methanol. Antibacterial activity test showed that the methanol extract of Eleiodoxa conferta fruit peel can provide inhibition of bacterial growth greater than n-hexane and dichloromethane extracts. Methanol extract was fractionated using liquid vacuum chromatography (KVC) to obtained active fractions containing phenolic compounds. The content of phenolic compounds in the active fractions of methanolic extract of Eleiodoxa conferta fruit peel produce zone of growth inhibition of Streptococcus mutans bacteria by TLC-contact bioautography test.
\end{abstract}

Keywords: Eleiodoxa conferta, fruit peel, phenolic compounds, antibacterial, Streptococcus mutans

\begin{abstract}
ABSTRAK
Kulit buah asam paya (Eleiodoxa conferta (Griff.) Buret.) yang merupakan bahan yang tidak banyak dimanfaatkan, dilakukan uji aktivitas antibakteri terhadap Streptococcus mutans. Ekstraksi dilakukan dengan menggunakan pelarut dengan polaritas bertingkat yaitu nheksana, diklorometana, dan metanol. Uji aktivitas antibakteri menunjukkan ekstrak metanol kulit buah asam paya dapat memberikan daya hambat pertumbuhan bakteri lebih besar dari ekstrak n-heksan dan diklorometana. Ekstrak metanol difraksinasi dengan menggunakan kromatografi vakum cair (KVC) untuk mendapatkan fraksi aktif yang mengandung senyawa fenolik. Kandungan senyawa fenolik dalam fraksi aktif ekstrak metanol kulit buah asam paya menghasilkan zona hambat pertumbuhan bakteri Streptococcus mutans dengan uji KLTbioautografi kontak.
\end{abstract}

Kata kunci : Eleiodoxa conferta, kulit buah asam paya, senyawa fenolik, antibakteri, Streptococcus mutans 


\section{PENDAHULUAN}

Tanaman Eleiodoxa conferta (Griff.) Buret. yang termasuk dalam famili Arecaceae, di daerah Kalimantan Tengah dikenal dengan sebutan asam paya. Asam Paya (Eleiodoxa conferta (Griff.) Buret) secara tradisional dimanfaatkan sebagai obat sariawan dan digunakan masyarakat sebagai pemberi rasa asam dalam masakan. Kandungan asam organik (Mokhtar dkk., 2015), senyawa fenolik, flavonoid, dan saponin (Afriani dkk., 2014) dan alkaloid dilaporkan terkandung dalam buah Eleiodoxa conferta (Sari dkk., 2019).

Buah asam paya diketahui mempunyai aktivitas sebagai antiokdisan (Afriani dkk., 2014), antibakteri beberapa jenis bakteri seperti Staphylococcus aureus, Salmonella thypi (Safitri dkk., 2017) dan Escherichia coli (Sari dkk., 2020). Buah asam paya juga telah dilaporkan berpotensi sebagai sensitizer alami Dye-Sentisized Solar Cell karena ekstrak terdeteksi memiliki gugus karbonil dan hidroksil (Jaafar dkk., 2017). Gugus hidroksil yang merupakan ciri dari senyawa fenolik merupakan kandungan kimia dari banyak bahan alam, yang berkaitan erat dengan beberapa aktivitas seperti antioksidan dan antibakteri. Beberapa senyawa fenolik seperti epigalokatekingalat, asam tanat, kuersetin, dan juga epikatekin diketahui dapat menghambat pertumbuhan bakteri $\beta$-laktam (Mandal dkk., 2017). Buah yang banyak mengandung senyawa fenolik berpotensi digunakan sebagai antibakteri alami (Fu dkk., 2016).

Sebagai salah satu pemanfaatan asam paya oleh masyarakat yaitu dalam menjaga kesehatan mulut, maka mikroorganisme dalam mulut merupakan hal yang perlu diperhatikan. Salah satu bakteri yang dapat menyebabkan gangguan mulut adalah Streptococcus mutans. Streptococcus mutans dapat menempel pada permukaan gigi sehingga menyebabkan plak dan koloni di permukaan gigi, hal ini mengarah pada terbentuknya karies gigi (Zaenab dkk., 2004). Untuk itu diperlukan suatu bahan antibakteri. Buah asam paya telah dilaporkan berpotensi sebagai antibakteri karena mengandung senyawa fenolik. Pemanfaatan buah asam paya ini menyisakan bahan lain yang tidak digunakan yaitu kulit buah, yang dalam hal ini belum banyak diteliti. Pemanfaatan bahan alam berupa kulit buah asam paya ini menjadi perlu diteliti untuk mendapatkan senyawa fenolik yang berpotensi antibakteri alami.

Penelitian ini bertujuan untuk mengetahui kandungan senyawa dalam kulit buah asam paya (Eleiodoxa conferta (Griff.) Buret.) dari Kalimantan Tengah, juga potensi kulit buah asam paya sebagai antibakteri terhadap Streptococcus mutans. Lebih lanjut senyawa fenolik yang aktif antibakteri difraksikan dari ekstrak aktif kulit buah asam paya.

\section{METODE PENELITIAN}

\section{Alat dan Bahan}

Persiapan bahan

Buah asam paya (Eleiodoxa conferta (Griff.) Buret.) diperoleh dari daerah Kumai, Kotawaringi Barat, Kalimantan Tengah. Bahan penelitian yang digunakan adalah kulit buah asam paya, dikeringkan dalam lemari pengering pada suhu $50^{\circ} \mathrm{C}$ dan dihaluskan. Serbuk kemudian diayak dengan ayakan 30/40.

\section{Ekstraksi}

Ekstraksi $\begin{gathered}\text { dilakukan } \\ \text { bertingkat }\end{gathered} \begin{array}{r}\text { secara } \\ \text { dengan }\end{array}$
mexhletasi
menggunakan pelarut n-heksana,
diklorometana dan metanol. Ekstraksi
dilakukan dari pelarut yang memiliki
tingkat kepolaran rendah sampai kepo-
laran tinggi yaitu n-heksana (index po-
laritas 0) diharapkan dapat menyari
kandungan senyawa non polar,
diklorometana (index polaritas 3,1) un-
tuk menyari kandungan semipolar dan
metanol (index polaritas 5,1) untuk
menyari kandungan senyawa polar dari


kulit buah asam paya. Masing-masing ekstrak yang diperoleh, kemudian dipekatkan menggunakan penguap vakum berputar, sehingga diperoleh ekstrak nheksana, ekstrak diklorometana, dan ekstrak metanol kental. Ekstrak kental yang diperoleh kemudian dihitung rendemen.

\section{Uji kandungan kimia ekstrak}

Pengujian dilakukan untuk mendapatkan gambaran umum tentang kandungan senyawa flavonoid, tanin, terpenoid, saponin dan alkaloid di dalam ekstak n-heksana, diklorometana, dan metanol. Uji kandungan kimia dilakukan dengan uji pendahuluan dan uji penegasan (KLT).

\section{Uji Aktivitas Antibakteri}

Aktivitas antibakteri terhadap bakteri Streptococcus mutans dilakukan dengan metode difusi sumuran. Media yang digunakan adalah Mueller Hinton Agar (MHA). Konsentrasi bakteri menggunakan standar $1 / 2$ Mc Farland, dengan kekeruhan yang setara 1,5 x 108 CFU/mL (Soraya dkk., 2018). Sampel uji berupa ekstrak n-heksana, diklorometana, dan metanol kulit buah asam paya (Eleiodoxa conferta (Griff.) Buret.) dengan konsentrasi 5, 10, dan $20 \%$ dalam pelarut dimetil sulfoksida (DMSO). Siprofloksasin $\quad 0,05 \%$ digunakan sebagai kontrol positif dan DMSO sebagai kontrol negatif. Media kemudian diinkubasi pada suhu $37 \mathrm{oC}$ selama 24 jam. Diameter zona bening yang merupakan aktivitas penghambatan pertumbuhan bakteri diukur menggunakan jangka sorong. Pengujian aktivitas dilakukan pengulangan lima kali.

Analisis data berupa diameter zona bening dari ekstrak n-heksana, diklorometana, dan metanol kulit buah asam paya (Eleiodoxa conferta (Griff.) Buret.) diuji beda menggunakan Anova dua jalan secara statistika (SPSS versi 19.0).

\section{Fraksinasi}

Fraksinasi dalam penelitian ini dilakukan dilakukan dengan cara kromatografi kolom vakum cair (KVC). Fase diam yaitu silika gel GF254 dan fase gerak yang digunakan adalah nheksana : etil asetat : metanol dengan perbandingan tertentu. KVC dilakukan dengan menggunakan ekstrak metanol kulit buah asam paya (Eleiodoxa conferta (Griff.) Buret.) dengan pertimbangan untuk memisahkan senyawa fenolik yang aktif antibakteri.

Hasil KVC sebanyak 11 fraksi diuji KLT untuk mengetahui kandungan senyawa fenolik. Kemudian dilanjutkan uji KLT bioautografi kontak untuk mengetahui senyawa fenolik yang mempunyai aktivitas antibakteri terhadap Streptococcus mutans.

\section{Uji KLT Bioautografi Kontak}

Ekstrak ataupun fraksi dilakukan uji KLT bioautografi kontak. Ekstrak atau fraksi ditotolkan pada lempeng KLT silika gel GF $254 \mathrm{~nm}$ dan dielusi menggunakan eluen etil asetat : metanol : air (100:13,5:10) dan penampak bercak larutan $\mathrm{FeCl} 3$. Lempeng silika dikeringkan, dan ditempelkan selama 30 menit pada $40 \mathrm{ml}$ media MHA yang telah diinokulasikan 1,00 $\mathrm{ml}$ suspensi bakteri Streptococcus mutans. Media kemudian diikubasi pada suhu $37 \mathrm{oC}$ selama 24 jam dan dianalisis zona bening yang terbentuk.

\section{HASIL DAN PEMBAHASAN}

Rendemen ekstrak n-heksana, diklorometana, dan metanol kulit buah asam paya (Eleiodoxa conferta (Griff.) Buret.) diperoleh berturut-turut sebesar 7,60; 5,69; dan 16,11\%. Uji kandungan kimia dalam ekstrak menunjukkan kandungan senyawa terpenoid dalam ekstrak n-heksana. Ekstrak diklorometana dan ekstrak metanol mengandung senyawa fenolik dan terpenoid. Alkaloid tidak terdapat dalam ekstrak kulit buah asam paya. Ekstrak 
kulit buah asam paya mempunyai kesamaan kandungan dengan ekstrak buah asam paya, yang dilaporkan mengandung senyawa fenolik, flavonoid, dan saponin, serta tidak mengandung alkaloid (Afriani dkk., 2014). Namun alkaloid dilaporkan terkandung dalam air perasan buah Eleiodoxa conferta, begitu juga kandungan fenolik, flavonoid, dan saponin (Sari dkk., 2019).

Uji difusi sumuran pada ekstrak kulit buah asam paya menunjukkan bahwa pada konsentrasi 5\%, 10\%, 20\% dari ekstrak n-heksana, diklorometana, dan metanol, terdapat perbedaan aktivitas antibakteri (sig $<0,05$ ). Seluruh ekstrak memberikan aktivitas antibakteri terhadap bakteri Streptococcus mutans, ditunjukkan dengan diameter zona bening yang dihasilkan jika dibandingkan dengan kontrol negatif DMSO. Streptococcus mutans merupakan bakteri gram positif yang mempunyai struktur dinding sel yang lebih sederhana dibandingkan dengan bakteri gram negatif, sehingga senyawa antibakteri mudah masuk ke dalam tubuh bakteri (Surtina dkk., 2020). Peningkatan konsentrasi ekstrak yang digunakan memberikan diameter zona bening yang semakin besar pula. Hal ini menunjukkan bahwa peningkatan konsentrasi ekstrak berpengaruh terhadap peningkatan aktivitas antibakteri terhadap bakteri Streptococcus mutans. Ekstrak kulit buah asam paya mempunyai aktivitas antibakteri yang kuat dengan diameter zona hambat antara 10-20 mm (Safitri dkk., 2017), walaupun ekstrak n-heksan dan diklorometana 5\% masih memberikan aktivitas antibakteri sedang. Hal tersebut dikarenakan perbedaan senyawa aktif dari ekstrak nheksana, ekstrak diklorometana dan ekstrak metanol sehingga kemampuan sampel dalam menghambat bakteri juga berbeda (Gambar 1).

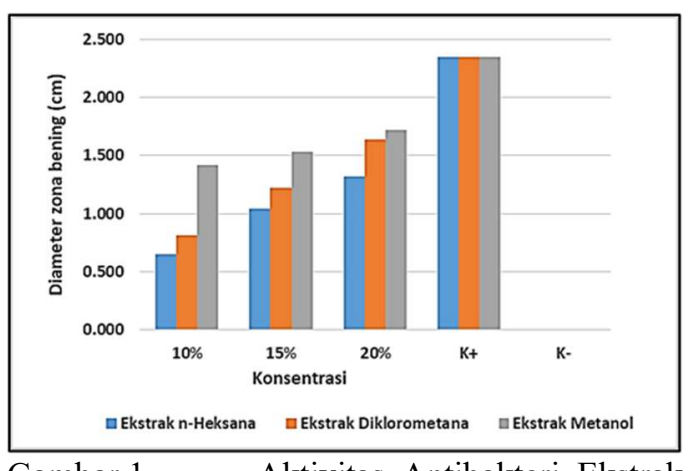

Gambar 1. Aktivitas Antibakteri Ekstrak Kulit Buah Asam Paya Terhadap Bakteri Streptococcus mutans.

Ekstrak metanol yang mengandung senyawa fenolik, memiliki daya hambat berupa diameter zona bening paling besar di antara ekstrak nheksana dan ekstrak diklorometana. Senyawa fenolik seperti flavonoid ataupun asam fenolat dapat memberikan aktivitas antibakteri baik pada bakteri gram positif maupun gram negatif (Puupponen-pimia dkk., 2001). Kandungan senyawa fenolik dalam ekstrak metanol dipisahkan dengan cara KVC dan diperoleh 11 fraksi. Hasil KLT fraksi dengan menggunakan sistem KLT yang sesuai menunjukkan kandungan senyawa fenolik dalam fraksi 4 (F4) dan fraksi 5 (F5) dengan hRf 80 (Gambar 2). F4 dan F5 merupakan fraksi yang mengandung senyawa fenolik yang relatif dapat terpisahkan dengan baik dari kandungan senyawa lain di dalam ekstrak. Selanjutnya fraksi tersebut merupakan fraksi aktif antibakteri terhadap bakteri Streptococcus mutans karena memberikan zona hambat pertumbuhan bakteri berupa zona bening dengan hRf 80, yang sama dengan hasil KLT (Gambar 3).

Kandungan senyawa fenolik seperti fenol hidrokuinon ataupun flavonoid dalam buah asam paya (Eleiodoxa conferta (Griff.) Buret.) dilaporkan dapat memberikan aktivitas antibakteri (Sari dkk., 2019). Flavonoid dapat merusak membran sel bakteri yang menyebabkan cairan intrasel bakteri keluar, dan bakteri mati. Contoh 
suatu senyawa flavonoid antibakteri, kuersetin, dapat menghambat pembentukan lipase bakteri yang berpengaruh dalam pembentukan peptidoglikan. Begitu pula dengan senyawa fenolik lain seperti rutin dan epikatekin mempunyai potensi sebagai antibakteri (Sahloul dkk., 2014).

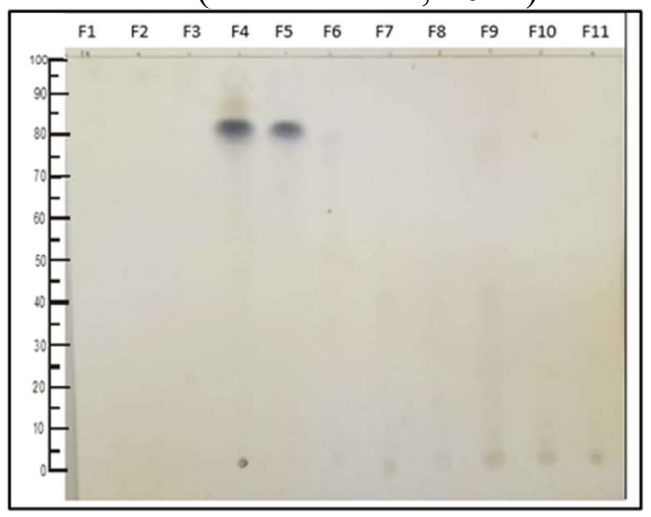

Gambar 2. Hasil KLT Fraksi dari Ekstrak Metanol Kulit Buah Asam Paya (Eleiodoxa conferta (Griff.) Buret.)

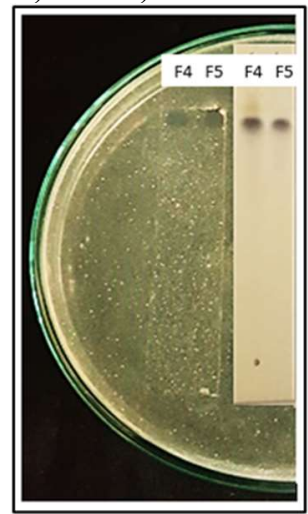

Gambar 3. KLT Bioautografi Fraksi Aktif yang Mengandung Senyawa Fenolik

\section{KESIMPULAN}

Kulit buah asam paya (Eleiodoxa conferta (Griff.) Buret.) berpotensi sebagai antibakteri terhadap pertumbuhan bakteri Streptococcus mutans. Ekstrak n-heksana, diklorometana, dan metanol dengan konsentrasi 5\% sudah dapat memberikan aktivitas antibakteri. Kandungan senyawa fenolik dalam fraksi yang diperoleh dari pemisahan ekstrak metanol mempunyai potensi sebagai antibakteri.

\section{SARAN}

Perlu dilakukan pemisahkan lebih lanjut dan dilakukan uji aktivitas antibakteri yang berspektrum luas bukan hanya untuk bakteri gram positif, namun juga untuk bakteri gram negatif. Pengembangan dalam bentuk sediaan farmasi yang sesuai juga perlu dilakukan untuk mendapatkan sediaan antibakteri dengan senyawa antibakteri dari bahan alam, terutama pemanfaatan limbah bahan alam seperti kulit buah asam paya.

\section{DAFTAR PUSTAKA}

Afriani S., Indiawati N., Destiarti L., Arianie L. 2014. Uji Aktivitas Antioksidan Daging Buah Asam Paya (Eleiodoxa conferta Burret) Dengan Metode DPPH dan Tiosianat. JKK. 3 (1) : 49-56

Depkes RI. 1995. Material Medika Indonesia. Jilid VI. Cetakan VI. Jakarta : Departemen Kesehatan RI.

Djamil R., Anelia T. 2009. Penapisan Fitokimia. Uji BSLT dan Uji Antioksidan Ekstrak Metanol Beberapa Spesies Papilionaceae. Jurnal Ilmu Kefarmasian Indonesia. 7 (2) : 65-71.

Fu L., Lu W.Q., Zhou X.M. 2016. Phenolic Compounds and In Vitro Antibacterial and Antioxidant Activities of Three Tropic Fruits: Persimmon, Guava, and Sweetsop. BioMed Research International. Article ID 4287461. DOI: $10.1155 / 2016 / 4287461$

Hanani E. 2015. Analisis Fitokimia. Jakarta : Penerbit Buku Kedokteran. EGC.

Jaafar H., Ain M.F., Ahmad Z.A. 2018. Performance of E. conferta and $\mathrm{G}$. atroviridis fruit extracts as sensitizers in dye-sensitized solar cells (DSSCs). Ionics. Springer. DOI 10.1007/s11581-017-2244-1

Mandal S.M., Dias R.O., Franco O.L. 2017. Phenolic Compounds in 
Antimicrobial Therapy. Journal of Medicinal Food. 2017: 1-8. DOI: 10.1089/jmf.2017.0017

Mokhtar S.I., Aziz N.A.A. 2015. Organic Acid Content and Antimicrobial Properties of Eleiodoxa conferta Extracts at Different Maturity Stages. J. Trop. Resour. Sustain.Sci. 3 (2015) : 72-76

Puupponen-Pimia R., Nohynek L., Meier C., Kahkonen M., Heinonen M., Hopia A., OksmanCaldentey K.-M. 2001. Journal of Applied Microbiology. 90 : 494507. DOI: $10.1046 /$ j.13652672.2001.01271.x

Rumouw D. 2017. Identifikasi dan Analisis Kandungan Fitokimia Tumbuhan Alam Berkhasiat Obat yang Dimanfaatkan Masyarakat Sekitar Kawasan Hutan Lindung Sahedaruman. Jurnal LPPM Bidang Sains dan Teknologi. 4 (2) : 53-66.

Sari R.P., Nazrun, Surtina, Mahardika R.G. 2019. Uji Fitokimia dan Aktivitas Antibakteri Pada Air Kelubi Terhadap bakteri Staphylococcus aureus. Prosiding Seminar Nasional Penelitian dan Pengabdian Pada Masyarakat. Pangkalpinang. 3-4 September 2019. 61-63.

Safitri G.L., Wibowo M.A., Indiawati N. 2017. Uji Aktivitas Ekstrak Kasar Buah Asam Paya (Eleiodoxa conferta (Griff.) Burret) Terhadap Bakteri Dan Staphylococcus aureus Dan Salmonella thypi. JKK. 6 (1) : 1720

Sahloul R.B., Fredj R.B., Boughalleb N., Shriaa J., Saguem S., Hilbert J.L., Trotin F., Ammar S., Bouzid S., Skhiri F.H. 2014. Phenolic Composition and Antioxidant and
Antimricrobial Activities of Extracts Obtained from Crataegus azarolus L. Var. Aronia (Willd.) Batt. Ovaries Calli. Journal of Botany. 2014: Article ID 623651. DOI:

http://dx.doi.org/10.1155/2014/62 3651

Septiana E., Simanjuntak P. 2015. Aktivitas Antimikroba dan Antioksidan Ekstrak Beberapa Bagian Tanaman Kunyit (Curcuma longa). Fitofarmaka. 5 (1) : $31-40$

Soraya C., Chismirina S., Novita R. 2018. Pengaruh Perasan Bawang Putih (Allium sativum L.) Sebagai Bahan Irigasi Saluran Akar Dalam Menghambat Pertumbuhan Enterococcus faecalis Secara In vitro. Cakradonya Dent J. 10 (1) : 1-9. $\quad$ DOI: https://doi.org/10.17969/rtp.v\%25 vi\%25i.10609

Surtina, Sari R.P., Zulita, Rani, Roanisca O., Mahardika R.G. 2020. Potensi Antibakteri Ekstrak Daging Buah Kelubi (Eleiodoxa conferta) Bangka Belitung Menggunakan MicrowaveAssisted Extraction (MAE). Indo. J. Chem. Res. 7 (2) : 177-182. DOI:

https://doi.org/10.30598//ijcr.2020 .7-sur

Wagner, H., Bladt S., Zgainski E.M. 1996. Plant Drug Analysis "A Thin Layer Chromatography Atlas". New York : Springer.

Zaenab, Mardiastuti H.W., Anny V.P., Logawa B. 2004. Uji Antibakteri Siwak (Salvadora persica Linn.) terhadap Streptococcus mutans (ATC31987) dan Bacteroides melaninogenicus. Makara Kesehatan. 8 (2) : 37-40. 